\title{
Some blood biochemical changes in response to saline exposure in the fresh water fish,Notopterus notopterus (Pallas)
}

\author{
K. S. Kavya, R. S. Kulkarni, M. Jadesh \\ Department of Studies in Zoology, \\ Gulbarga University, Kalaburgi (India) \\ Email address: rskgug@gmail.com
}

Keywords: Blood chemical parameters; saline medium, fish blood, Notopterus notopterus

\begin{abstract}
The changes in some blood biochemical parameters were studied in the freshwater fish N. notopterus under saline exposure for a longer period of 30 days. The blood biochemical parameters are glucose, protein, triglycerides and cholesterol. All these parameters exhibited increased level except of blood glucose which remained unchanged as observed after the termination of saline exposure. Thus it indicates that although fish survives and able to tolerate extreme saline condition as there was no mortality during the exposure period. The increase of blood biochemical parameters can be considered as a kind of saline stress response particularly on lipid derivatives.
\end{abstract}

\section{INTRODUCTION}

The effects of stress resulting from aquaculture practices on fish and methods of minimizing such effects have received considerable attention through the years (Barton and Jwama, 1991, Mazik et al, 1991; Cech et al., 1996). Stress induced by common practices such as handling, crowding, transport or poor water conditions can increase the incidence if diseases and mortality and salinity fluctuations undoubtedly impose stress on the physiology of the exposed fish population and can modify their structure, and is therefore an important factor affecting the economics of aquaculture.

Stress disturb the final internal balance, homeostasis and has further determinable effects on behavior, growth, reproduction, immune function and disease tolerance (Chen et al.,2004; Morales et al.,2005). Fish has developed physiological and biochemical adaptations to cope with these constraints that minimize or eliminate the deleterious effects, which is called stress response. The evaluation of biochemical parameters has provided tool for facilitating fish health management (Chen et al, 2004). Blood chemistry parameters are used as indicators of physiological stress response in fish (Lerman et al, 2004; Koypuds et al, 2007). Saline stress response studies of fresh water fish $N$. notopterus are scanty, hence, the present study is undertaken to find out the saline stress response with emphasis on certain blood biochemical parameters.

\section{MATERIALS AND METHODS}

Fresh water fish Notopterus notopterus caught 30 fishes by a local fisher man from Bheema river $\left(16^{0} 24^{0} 36^{\prime \prime} \mathrm{N}, 77017^{\prime} 6\right.$ " E) near Gulbarga and brought to the laboratory. They were kept in 30L fiberglass tanks containing 30 liter aerated water. The fish were allowed to acclimate for a period of one week before start of the experiment. Among 30 fishes, 15 fishes were gradually and continuously exposed to saline medium starting from $1 \mathrm{gm}$ up to $50 \mathrm{gm}$ and final saline medium contains $50 \mathrm{~g} / 30$ liters of water and kept for 30 days. Equal number of fish was kept as control.

After the termination of the experiment exposing to saline medium for 30 days, the fish blood was collected from the caudal region with the aid of $2-3 \mathrm{~cm}$ disposable plastic syringes and a 21 gauge disposable hypodermic needle and transferred to plastic tubers. The sample was then mixed gently and thoroughly and blood samples were transferred to laboratory for testing the serum glucose, serum protein, serum triglycerides and serum cholesterol. 
Serum glucose was measured by GOD-POD, End point Assay and Kinetic Assay method, Serum protein was measured by using the modified Biuret method, GPO/PAP method (SR Kit) for the determination of triglycerides, (HOD/PAP method for the determination of cholesterol in blood serum.

Calculation: Salinity was found to be $0.16 \%$ or $1666.66 \mathrm{ppm}$, by following standard formula.ppm $=$ mass solute $(\mathrm{mg}) /$ volume solution $(\mathrm{L}), \mathrm{ppm}=50 \times 1000 / 30=1666.66 \mathrm{ppm}$, conversion of $\mathrm{ppm}$ to $\% ., \%=1666.66 \times 100 / 1000000=0.16 \%$.

\section{RESULT AND DISCUSSION}

The fresh water fish N.notopterus was exposed to $0.16 \%$ saline medium and on exposure for 30 days no mortality occurred and found that the fish can tolerate higher concentration of salinity even in the environment. The fish were comfortable with proper movement coming to the surface for gulping air. The results obtained have been presented in the table 1.There is no change in the serum glucose. The serum protein in control fish was $6.23 \mathrm{gm} / \mathrm{dl}$, while it was in experimental fish 8.43(Fish exposed to $0.16 \%$ salinity). There was $2.20 \mathrm{gm} / \mathrm{dl}$ increased in fish exposure to salinity. The serum triglycerides in control fish were $308.25 \mathrm{mg} / \mathrm{dl}$, in experimental fish it was $366.2 \mathrm{mg} / \mathrm{dl}$. There was considerable increase in the serum triglycerides in experimental fishes when compare to control fishes. The plasma cholesterol of control fish was $232.75 \mathrm{mg} / \mathrm{dl}$. The experimental fish serum cholesterol was found to be $450.5 \mathrm{mg} / \mathrm{dl}$. The serum cholesterol has been increased two fold in the experimental fishes

In the present investigation there was no change in the glucose level of fishes exposed to salinity $(0.16 \%)$. Gelis Tarihi (2004) reported that, there was no change in the glucose level of tilapia, Saratherodon melanotheron exposed to 9 ppt salinity, but glucose level was relatively high in fish exposed to $18 \mathrm{ppt}$ for 72 hours and the glycogen level in liver tissue significantly reduced $(\mathrm{P}<0.05)$, this shows that higher salinity results in high rate of glycogenolysis activity to meet high energy demand and that resulted in reduced glycogen levels in liver. From the study of Gelis Tarihi (2004) it is clear that as salinity increases glucose level increases, and fishes have the ability to withstand some saline stress, this is revealed in the fish exposed to 9 ppt salinity, it was similar to those of controlled fishes. The same result was also observed in our study in the fish Notopterus notopterus. There was no change in the blood glucose level at $0.16 \%$ salinity. Hyperglycemia is an expected result of stress or exhaustive exercise in fishes (Barton and Iwama 1991; Hrubec etal.,1997). Blood glucose levels may elevate immediately but catecholamines which facilitate gluconeogenesis (Baton and Iwama, 1991). It is known that the degree of hyperglycemia may change depending on the type of stress and the sampling times (Rotlland etal., 1997).

The concentration of total protein is used as a basic index for health status of fish (Mustafa et al., 2009) and it is an important non specific immune parameter (Magnadottir et al.,2006).In the present study there is an increase in the serum protein in experimental fishes. The control fish serum protein was $6.23 \mathrm{~g} / \mathrm{dl}$ and (experimental fish) fishes exposed to $0.16 \%$ was $8.43 \mathrm{gm} / \mathrm{dl}$. According to Rakovac et al, (2005), increased concentrations of total protein can be caused by structural liver alterations reducing aminotransferase activity impaired control of fluid balance.

Serum Kuck et al., (2012), also reported that there was increase in total protein as salinity increases. Their result was, at $50 \%(\mathrm{Sw})$ Salinity there total protein was $50.4 \pm 5.3$, at $100 \%(\mathrm{Sw})$ salinity the total protein was $40.0 \pm 7.9150 \%$ (Sw), at $150 \%$ salinity the total protein was $35.6 \pm 8.9$, at $200 \%$ (SW) salinity the total protein was 35.7 \pm 6.0 . On the contrary Mohammad Reza et al.,(2012) reported that serum protein levels decreased with increase in salinity. In their study serum protein was $48.33 \pm 6.51$ at $12 \mathrm{ppt}$ salinity, $53.00 \pm 4.00 \mathrm{mg} \mathrm{dl}-1$ at $6 \mathrm{ppt}$ and $64.00 \pm 4.58 \mathrm{mg} \mathrm{dl}-1$ at 0 ppt. Marcel et al.,(2009) reported that, in cells of stressed organisms there is an increase I $n$ the production of heat shock protein or stress protein which are required to assist the folding of nascent polypeptide chains, act as a molecular chaperone and mediated the repair and degradation of altered or denatured protein to maintain homeostasis. Protein are the most important and abundant macromolecules in living beings, which play a vital role in architecture and physiology of the cell and in cellular metabolism. Proteins also play an important role in the metabolism and regulation of 
water balance.(Heath etal.,1995). All biological activities are regulated by enzymes and hormones, which are also proteins. Assessment of protein content can be considered as a diagnostic tool to determine the physiological phases of the cells. (Kapila etal.,1991). The survival ability of animals exposed to stress mainly depends on their protein synthesis potential (Padma etal.,2012). The decrease in protein content was probably due to reduced/perturbation of microsomal protein synthesis. The degradation of protein suggests the increase in proteolytic activity and possible utilization on their product for metabolic purpose and cause damage (Padma etal., 2012).

The quantity of protein is dependent on the rate of protein synthesis or on the rate of its degradation (Catharios etal.,2004).

In the fish Notopterus notopterus, serum triglycerides level increase in experimental fishes by $57.95 \mathrm{mg} / \mathrm{dl}$. In experimental fish the triglycerides level was $366.2 \mathrm{mg} / \mathrm{dl}$ and in control fishes $308.25 \mathrm{mg} / \mathrm{dl}$. Arjon et al.(2009) also reported that serum triglycerides increased in Solea senegalensis, to the saline condition that is $208 \mathrm{mM}$ at $15 \mathrm{ppt}$ and $10.7 \mathrm{mM}$ at $39 \mathrm{ppt}$. the result of Serma etal.(2012) was completely reversed when compare that serum triglycerides significantly decreased in parallel with increase in salinity. The result of their report was $2.7 \mathrm{mM}$ at 8 ppt and $1.1 \mathrm{mM}$ at $24 \mathrm{ppt}$. And the same result was also reported by Mohammad Reza etal. (2012) in gold fish. In their study also the serum triglyceride level decreases with increase in salinity. At 0 ppt the serum triglyceride level was $306.67 \mathrm{mg} \mathrm{dl-1}$ and at $6 \mathrm{ppt}$ it was $294 \mathrm{mmdL}-1$ and at $12 \mathrm{ppt}$ it was 257.67 mgdl-1. However, in our study the triglycerides increased on exposure to saline medium and this may be because of increased in metabolic rate and demand for lipid accumulation.

Cholesterol is a necessary compound of the structure of the cell membrane. in fishes exposed to $0.16 \%$ salinity (Notopterus notopterus) was $450.5 \mathrm{mg} / \mathrm{dl}$. It is twofold more than that of control fishes. The same result is also for Yamawaki etal. (1986) and Sancho etal, (1997). According to them increased concentrations of cholesterol in serum can be a result of damages to liver or kidney. Elevated levels of cholesterol indicate disorders of lipid and lipoprotein metabolism, especially liver disease, (Kavadias etal., 2004), it is known that the serum biochemistry can be influenced by many biotic and abiotic factors such as water temperature, seasonal pattern, food, age and sex of the fish(Annino etal., 1976).In the present investigation the serum cholesterol the serum cholesterol levels was two fold increase in the saline exposed fishe compare to control fishes. Therefore a high concentration of blood cholesterol may suggest the dietary lipid imbalance.(Wedemeyer etal., 1990). This lipid imbalance in $N$. notopterus may be because of saline stress that leads to the imbalance of lipid metabolism.

\section{CONCLUSIONS}

The present study indicates that fish shows response physiologically by increasing the level of serum glucose, protein, triglycerides, and cholesterol, but there was no change in the glucose level. Hence the. fresh water fish Notopterus notopterus undergo many physiological changes by increasing the above blood parameters such as serum glucose, protein, triglycerides and cholesterol, so that it can withstand the saline stress to thrive well in the changed water environment under natural conditions.

Table-1: Showing some blood biochemical parameters in the fresh water fish,N.notopterus

\begin{tabular}{|c|l|c|c|c|c|c|c|}
\hline \multirow{2}{*}{ S.No } & \multirow{2}{*}{ Parameters } & \multicolumn{3}{|c|}{ Control Group } & \multicolumn{3}{c|}{ Experimental group } \\
\cline { 3 - 8 } & & Mean & SD & SE & Mean & SD & SE \\
\hline 1 & Serum Glucose & 72.16 & \pm 0.9 & 0.4 & 72.83 & \pm 0.7 & 0.3 \\
\hline 2 & Serum Protein & 6.23 & \pm 0.6 & 0.30 & 8.43 & \pm 0.7 & 0.3 \\
\hline 3 & Serum Triglycerides & 308.25 & \pm 1.1 & 0.5 & 366.2 & \pm 0.6 & 0.3 \\
\hline 4 & Serum Cholesterol & 232.75 & \pm 1.9 & 0.8 & 450.5 & \pm 1.8 & 0.8 \\
\hline
\end{tabular}

All values are expressed as means $\pm \mathrm{SD}, \mathrm{N}=6$, Glucose in $\mathrm{mg} / \mathrm{dl}$, Protein in gm/dl, Triglycerides in $\mathrm{mg} / \mathrm{dl}$ and Cholesterol in $\mathrm{mg} / \mathrm{dl}$. The serum glucose is $72 \mathrm{mg} / \mathrm{dl}$ in both control and experimental fishes. 


\section{Acknowledgements}

The authors are thankful to Gulbarga University for the nessessary facilities and RSK is grateful to University Grants Commission,New Delhi for Emeritus Fellowship.

\section{References}

[1] M.Y.Tsuzuki, K.Ogawa, C.A.Strussmann, M.Maita,F.Takashima; Physiological responses during stress and subsequent recovery at different salinities in adult pejerrey Odontesthes bonariensis, Aquaculture 200349-362(2001).

[2] R.Usha, Effect os salinity changes on haematological parameters of the tiger shark Pangasius hypophthalmus, J.Ecobiol,29(4)283-290(2011).

[3] Chen,C.,Wooster,G.A. and Bowser, P.R.,Comparative serum chemistry and histopathology of tilapia infected with Vibro vulnificus or Streptococcus iniae or exposed to carbo tetrachloride, gentamicin or copper sulfate, Aquaculture, 239,421-443(2004).

[4] Davis,K.B., Temperature effects physiological stress responses to acute confinement in sunshine bass (Morone chrysops $\mathrm{x}$ Morone saxatilis), comparative Biochemistry and Physiology, Part A, 139,433-440(2004).

[5] Goos,H.J.T. and Consten,D., Stress adaptation,Cortisol and pubertal development in the male common carp,Cyprinus carpio, Molecular and cellular Endocrinomogy, 197,105116,(2002).

[6] Ham,E.H.V., Anholt,R.D,V., Kruitwagen,G., Imsland, A.k., Foss, A., Sveinsbo, B.O., FitzGeraid,R., Paroura, A.C., Stefansson,S.O. and Bonga, S.E.W., Environment affects stress in exercised turbot, Comparative Biochemistry and Physiology, Part A,136,525538,(2003).

[7] Koeypudsa, W., Kitkamthorn, M., Sadu, K. and Sailasuta,A, Effects of short-term anoxian(Dooppm, hours) and long-term hypoxia (DO 3-4 ppm,90 days) on haematology of catfish, Journal of Health Research,21,13-24(2007).

[8] Lerman,C.L.,Lappe, R., Crestani,M., Vieria, V.P., Gioda, C,R., Schetinger,M.R.C., Bald isserotto,B., Moraes,G. and Morsch, V.M., Effect of different temperature regimes on metabolic and serum parameters of silver catfish Rhamdia quelen, aquaculture,239,497507(2004).

[9] Morales, A.E., Cardenete,G., abellan, E, and Garcia-Rejon,L.,Stress related physiological responses to handling in common dentex (Dentex dentex Linnaeus), Aquaculture Research, 36,33-40(2005).

[10] Tanck, M.W.T., Booms, G.H.R., Eding, E.H., Bonga, S.E. and Komen,J, Cold shocks: a stressor for common carp, Journal of fish Biology,57,881-894(2000).

[11] Barton, B.A., Iwama, G.K., Physiological changes in fish from stress in aquaculture with emphasis on the response and effects of corticosteroids, Annu.Rev Fish dis, 1,3-26(1991).

[12] Cech Jr., J.J., Bartholow, S.D., Young, P.S., Hopkins, T.E.,, Striped bas exercise and handling stress in freshwater: physiological responses to recovery environment, Trans,Am.Fish,Soc, 125,308-320(1996).

[13] Mazik, P.M., Simco, B.A., Parkern N.C., Influence of water hardness and salts on survival and physiological characteristics of striped bass during and after transport,Trans Am.Fish,Soc, 120,121-126(1991).

[14] Wedemeyer, G.A.,,Some physiological consequences of handling stress in the juvenile coho salmon (Oncorhynchus kisutch) and steelhead trout (Salmo gairdneri),J.Fish.Res.Board Can,,29,1780-1783(1972).

[15] Gelis Tarihi,Secondary stress Response of Nile tilapia, Oreochromis niloticus. After direct Transfer to different Salinities. Tarim Bilimleri Dergisi,11(2)139-141(2005). 
[16] Mohammad Reza Imanpoor, Esfondyar Najafi and Milad Kahir, Aquaculture Research, 43,332-338(2012).

[17] ArjonaF.J.,Vargas-Chacoff L, Ruz- Jarabol, Goncalves O, Pascoal, Martin del Rio MP, Mancera J M, Teritary stress responses in Senegalese sole (Solea senegalensis Kaup,1858) to osmotic challeng: implication for osmoregulation, energu metabolism and growth, J.Aquaculut,287,419-426(2009).

[18] Kavadias s., Castritsi-Catharios J, DessyprisA : Annual cycles of growth rate, feeding rate, food conversion, serum glucose and serum lipids in the population of European sea bass (Dicentrarchus labrax) farned in floating marine cages, JAPPICHTHYOI, 19, 2934(2004).

[19] Annino J.S. Clinical chemistry principles and procedures, Little , Brown Company, $4^{\mathrm{TH}}$ edition Edited by Giese, Roger W, P,230-257,Bostan(1976).

[20] Padma.P.B., Rachel,V., Maruthi.Y.A., Acute toxicity effect of imidacloprid insecticide on serum biochemical parameters of fresh water teleost Channa punctatus, IntJnt Sci Inn Tech Sec A Jun,1(2);18-22,(2012).

[21] Heath A.G., Water pollution and Fish Physiology, CRC. Press.INC. Boca.Raton,Florida, 359,(1995).

[22] Kapila M, Raghothaman G., Mercury Copper and Cadmium induced changes in the total protein level muscle tissue of an edible estuarine fish Boleophthalmus dessumieri, UV Envi Biol,20(3):231-234(1999).

[23] Magnnadottir B: Innate immunity of fish (over view), Fish and shellfish, Immunology, 20,137-151(2006).

[24] Mohammad Reza Imanpoor, E .s.fonyer Najafi and Milad Kahir, Effect of different salinity and temperatures on thr growth, survival, haematocrit and serum biochemistry of Gold fish (Carassius auratus), Aquaculture Research, 43.332-338(2012).

[25] Yamawaki K., Hashimoto., Fujii K., Koyama J., Ikeda Y and Ozaki H., Hemochemical changes in carp (Cyprinus carpio) exposed to low cadmium concentratons. Bullein of the Japanese Society of Scientific Fisheris 59,459-466, (1986).

[26] Sancho E., Ferrando M.D. and Andreau E, Sub lethal effects of an organophosphate insecticide on the European eel (Anguilla anguilla) Eco toxicology and Environmental safety,36,57-65(1997).

[27] Marcel Martinez0Porchas, Luis Rafael Martinez-Cordova and Rogelio Ramos- Enriquez, Cortisol and Glucose: Reliable indicators of fish stress ? Pan -American Jornal ofd Aquatic Science,4(2), 158-178(2009).

[28] Co-Rakovac, Strunjal-Perovicl, Hacmanjek M, Topic P n, Lipezz, Sostanic b: Serum chemistry and histological properties of wild and cultured sea bass (Dicentrarchus labrox) in the North Adriatic Sea. Vet Res common ,29,677-687(2005).

[29] Bartoon, B. A. and G.K. Iwama, Physiological changes in fish from stress in aquaculture with emphasis on the response and effects of cortiocosteroids- Annual Review of fish Diseases, 1:3,3-26(1991).

[30] Mostafa,AZ.M., Ahamad .M.H., Mousallamy .A. and Samir.A., Effects of using dried fenugreeh seeds as natural feed additives on growth performance, feed utilization, whole body composition and entropathogenic Aeromonas hydrophila chaliing of monosex Nile tilapia (Oreochromis niluticus) fingerlings, Australian Journal of Basic and Applied Science 3,1234-1245(2009).

[31] Rotllant, J.M., Pavlidis, M.Kentouri, M.E.Abad and L.Tort, Non specific immune responses in the red porgy Pargus pargus after crowdinh stress, Aquaculture, 156,279-290(1997). 